\title{
Factors Affecting The Timeliness Of Submission Of Financial Reports Of Public Companies In The Manufacturing Sector To Bapepam-LK
}

\author{
Arneta Martciesa \\ Department of Accounting, Univesity Of North Sumatra, Indonesia
}

\begin{abstract}
ARTICLE INFO
Article history:

Received Sep 12, 2021

Revised Oct 16, 2021

Accepted Nov 30, 2021

Keywords:
Timeliness;
Profitability;
Ownership Structure;
Quality Of Audior;
Company Age;
Company Size;
Financial Statement.

ABSTRACT

This research was conducted to examine the effect of variable Capital Adequacy Ratio (CAR), Non-Performing Financing (NPF), Operating Expenses Operating Income (BOPO), and Financing to Deposit Ratio (FDR) of Profitability (ROA). Profitability is used to measure the effectiveness of management based on results generated from the loan repayment and investment. The ratio is important for the bank's profitability is Return On Assets (ROA). Financial ratios that affect the ROA is the CAR, NPF, BOPO, and FDR. The sampling technique used was purposive sampling with the criteria of Islamic commercial bank serving the financial statements of the period December 2006September 2010. The analysis technique used is the classical assumption of the analysis, multiple regression analysis and hypothesis test with a level of significance of $5 \%$. The results of the research simultaneously (test F) states that the CAR, NPF, BOPO, and FDR jointly affect the profitability (ROA) of banks. While the results show that the correlation coefficient between profitability (ROA) of banks with 4 independent variables of $73.9 \%$. And the result of research partially $(\mathrm{t})$ states that the variable CAR and FDR did not have a significant positive effect on profitability (ROA) of banks. And variable BOPO NPF and significant negative effect on profitability (ROA) of banks.
\end{abstract}

This is an open access article under the CC BY-NC license.

\section{Corresponding Author:}

Arneta Martciesa,

Department of Accounting,

University Of North Sumatra, Indonesia,

Jl. Dr. Mansur No. 9 Padang Bulan, Kec. Medan Baru, Kota Medan 20222.

Email: arnetamartciesa@gmail.com

\section{INTRODUCTION}

Financial reports as a form of management accountability to shareholders and also for decision making. The financial report submitted to the Capital Market Supervisory Agency (Bapepam) is a financial report that has been audited by a certified public accountant and is accompanied by an audit opinion. The information in the financial statements is the responsibility of the company's management, but the audit opinion (opinion) is the responsibility of the auditor. Financial statements also provide information about the financial position, company performance, and changes in financial position. This has resulted in an increasing demand for audits of financial statements. Financial statements must meet four qualitative characteristics which are the characteristics that make financial statement information useful to its users.

To obtain the relevant information, there are several obstacles, one of which is timeliness. Financial statement information will have benefits if it is conveyed to users in a timely manner for 
decision making. Timeliness is one of the main elements in the financial statements. The benefits of a financial report will be reduced if the report is not available on time (IAI, 2007, PSAK No.1 par 38). The existence of regulations should encourage public companies to submit annual financial reports on time. However, in reality every year there are companies that are late in submitting their annual financial reports to BAPEPAM, while the regulations that apply during that period are still the same and have not changed. Regulation cannot be the only factor influencing public companies to submit financial reports on time in each period. However, it is also necessary to pay attention to other factors that cause delays in the completion of the presentation of financial statements. These factors are not limited to financial factors but also non-financial factors.

Several studies have been conducted by previous researchers to examine the effect of company-specific factors on the timeliness of the company's financial reporting. Owusu and Ansah (2000: 20) have examined the factors that affect the timeliness of financial statements in the Zimbabwean capital market (Zimbabwe Stock Exchange / ZSE) and found empirical evidence that only company size and profitability affect the timeliness of submitting audited financial statements. .

The results of Saleh's research (2004: 58) only found one empirical evidence, namely the extraordinary variable which has a significant effect on the timeliness of financial reporting of manufacturing companies while the gearing ratio, company size, company ownership structure, profitability, company age variables have no effect on the timeliness of financial reporting. manufacturing company on the Jakarta Stock Exchange. Oktorina and Suharli (2005) research shows empirical evidence that firm size, ownership structure, and large accounting firms affect the timeliness of corporate financial reporting. Meanwhile, debt to equity ratio and profitability have no significant effect on the timeliness of financial reporting.

Furthermore, researchers Pamor Mentari (2007: 98) have conducted research whose results show that only auditor reputation has a significant effect on the timeliness of publication of financial statements to the public, while profitability, gearing ratios, company size and company age have no effect on the timeliness of financial statement publications. to the public. Researcher Rini Dwiyanti (2010: 82) has examined variables such as debt to equity ratio, profitability, ownership structure, auditor quality and auditor turnover. The results show that profitability and ownership structure have a significant effect on the timeliness of financial reporting for manufacturing companies while the debt to equity ratio, auditor quality and auditor turnover have no effect on the timeliness of financial reporting of manufacturing companies. Meanwhile, Renny Catrinasari's research (2006:63) gives the result that gearing ratio, profitability, firm size, firm age have a significant effect on the timeliness of financial reporting of banking companies, while ownership structure has no effect on the timeliness of financial reporting.

Research by Renny Catrinasari (2006) and Rini Dwiyanti (2010) regarding profitability which has an influence on the accuracy of financial reporting contradicts the results of research by Saleh (2004) and Pamor Mentari (2007) which state that profitability has no effect on the accuracy of financial reporting. In the research of Oktaria and Suharli (2005) and Rini Dwiyanti (2010) stated that the ownership structure has an influence on the accuracy of financial reporting which is contrary to the opinion of Saleh (2004) and Renny Catrinasari (2006). While the results of research by Pamor Mentari (2007) regarding the reputation of public accounting firms that affect the timeliness of financial reporting contradict the results of research by Rini Dwiyanti (2010).

\section{RESEARCH METHOD}

This research includes comparative causal research. According to Erlina (2007: 14) the definition of comparative causal research is "Comparative causal research is a type of research with the characteristics of the problem in the form of a causal relationship between two or more variables".

Comparative causal research is ex post facto research, which is a type of research on data collected after the occurrence of a fact or event. This study uses a quantitative approach which emphasizes theory testing through measuring research variables with numbers and analyzing data using statistical procedures.

\subsection{Method of collecting data}

The data collection method used in this research is the documentation method. Documentation is the process of obtaining documents by collecting and studying the required documents or data 
(Wahyu Adhi, 2010: 58). The documents in question are independent auditor reports and the annual financial statements of public companies in the manufacturing sector contained in the Indonesian Capital Market Directory (ICMD) and the websitewww.idx.co.id years 2007 - 2010 to obtain data on profitability variables, ownership structure, reputation of auditors / Public Accounting Firms, company age and company size as well as literature study to obtain the theories behind the research.

\section{RESULTS AND DISCUSSIONS}

\subsection{Descriptive Statistical Analysis}

Descriptive statistics are statistics that function to describe or provide an overview of the object under study through sample or population data as it is, without conducting analysis and making conclusions that apply to the public. Description of a data seen from the average value (mean), standard deviation, maximum, minimum. The following shows statistical data in general from the overall data used in table 1.

Table 1. Descriptive Statistics

\begin{tabular}{cccccc}
\hline & N & Minimum & Maximum & mean & $\begin{array}{c}\text { Std. } \\
\text { Deviation }\end{array}$ \\
\hline ROA & 280 & -88.00 & 148.00 & 7.2500 & 15.54995 \\
OWN & 280 & 10.00 & 100.00 & 52.1071 & 23.58427 \\
HOOD & 280 & .00 & 1.00 & .4929 & .50084 \\
AGE & 280 & 2.00 & 20.00 & 13.5250 & 3.78254 \\
SIZE & 280 & 6352.00 & 29700914.00 & $2.4287 \mathrm{E} 6$ & $4.16180 \mathrm{E} 6$ \\
TIME & 280 & .00 & 1.00 & .9429 & .23253 \\
Valid N (listwise) & 280 & & & & \\
\hline
\end{tabular}

Source: Appendix C-1

Table 1. above shows that:

a. The profitability variable has a minimum value of -88.00 and a maximum of 148.00 with an average value of 7.2500 and a standard deviation of 15.54995. The amount of data used is 280 .

b. The ownership structure variable has a minimum value of 10.00 and a maximum of 100.00 with an average value of 52.1071 and a standard deviation of 23,58427 . The amount of data used is 280 .

c. The auditor reputation variable / Public Accounting Firm has a minimum value of 0.00 and a maximum of 1.00 with an average value of 0.4929 and a standard deviation of 0.50084 . The amount of data used is 280 .

d. The variable age of the company has a minimum value of 2.00 and a maximum of 20.00 with an average value of 13,5250 and a standard deviation of 3.78254 . The amount of data used is 280.

e. Firm size variable has a minimum value of 6352.00 and a maximum of 29700914.00 with an average value of 2.4287E6 and a standard deviation of $4.16180 \mathrm{E} 6$. The amount of data used is 280 .

f. The timeliness variable has a minimum value of 0.00 and a maximum of 1.00 with an average value of 0.9429 and a standard deviation of 0.23253 . The amount of data used is 280 .

\subsection{Statistical Analysis}

The statistical analysis used in this chapter is logistic regression. The analysis is used to test the research hypothesis, which relates to the effect of profitability, ownership structure, reputation of auditors / Public Accounting Firms, company age and size of public companies in the manufacturing sector on the timeliness of submitting financial statements. Hypothesis testing includes (1) assessing the feasibility of the regression model, (2) assessing the overall model and (3) testing the regression coefficient (Ghozali, 2001: 218).

\section{a. Assessing the Feasibility of the Regression Model (Goodness of Fit Test).}


The first step is to assess the feasibility of the regression model, taking into account the goodness of fit test value as measured by the chi-square value shown at the bottom of Hosmer and Lemeshow.

Table 2. Hosmer and Lemeshow Test

\begin{tabular}{cccc}
\hline Step & Chi-square & df & Sig. \\
\hline 1 & 12,483 & 8 & .131 \\
\hline Source: Appendix C-2 & & &
\end{tabular}

From table 2 above, it can be seen that the statistical value of Hosmer and Lemeshow goodness of fitness test is 12,483 with a significance probability of 0.131 . Because the probability value $>0.05$ then $\mathrm{HO}$ is accepted. This means that the regression model is suitable for further analysis because there is no significant difference between the predicted classification and the observed classification.

\section{b. Assessing the Overall Model (Overall Model Fit Test).}

The second step is to assess the overall model which is carried out by taking into account the value between -2Log Likelihood (-2LL) at the beginning (Block Number $=0)$ and -2Log Likelihood ($2 \mathrm{LL})$ at the end (Block Number $=1$ ).

Table 3. Overall Model Fit Test

\begin{tabular}{cc}
\hline Block Number $=0$ & Block Number $=1$ \\
-2 Log Likelihood & -2 Log Likelihood \\
\hline 122.658 & 103,628 \\
\hline Source: Appendix C-2 &
\end{tabular}

From table 3 above, it can be seen that the overall model fit at $-2 \mathrm{LL}$ Block Number $=0$ indicates a decrease in $-2 \mathrm{LL}$ Block Number $=1$. This decrease in likelihood indicates that the hypothesized model fits the data.

\section{c. Testing the Regression Coefficient / Research Hypothesis}

The last step is to test the regression coefficient / research hypothesis. Based on data processing with SPSS, this study shows the Cox \& Snell R Square value of 0.066 and the Nagelkerke $R$ Square value of 0.185 , which means that the variability of the dependent variable which can be explained by the variability of the independent variable is 18.5 percent. Table 4.8 below shows the test results using logistic regression at a significance level of 5 percent.

Table 4. Logistics Regression Coefficient Test Results

\begin{tabular}{ccccccc}
\hline & B & SE & Wald & df & Sig. & Exp(B) \\
\hline ROA & .038 & .015 & 6.012 & 1 & .014 & 1.038 \\
OWN & .010 & .013 & .669 & 1 & .413 & 1.010 \\
HOOD & -1.575 & .616 & 6,540 & 1 & .011 & .207 \\
AGE & -.152 & .086 & 3.126 & 1 & .077 & .859 \\
SIZE & .000 & .000 & 2,691 & 1 & .101 & 1,000 \\
Constant & 4.621 & 1,560 & 8,780 & 1 & .003 & 101.592 \\
\hline Source: Appendix C-2 & & & & & &
\end{tabular}

\section{d. Research Hypothesis Testing}

1) $\mathrm{H} 1$ : The profitability of public companies in the manufacturing sector affects the timeliness of submitting financial reports. The first hypothesis of this study assumes that the variable profitability of public companies in the manufacturing sector affects the timeliness of submitting financial statements. The ROA variable in table 4.5 of the regression model shows a positive coefficient value of 0.038 with a variable probability of 0.014 below the significance level 0.05 (5 percent). The results of testing this hypothesis indicate that the profitability of public companies in the manufacturing sector has a positive effect on the timeliness of submitting the company's financial statements. 
2) H2: The ownership structure of public companies in the manufacturing sector affects the timeliness of submitting financial reports. The second hypothesis of this study suspects that the variable ownership structure of public companies in the manufacturing sector affects the timeliness of submitting financial statements. The OWN variable in table 4.5 of the regression model shows the coefficient value positive 0.010 with a variable probability of 0.413 above the significance level of 0.05 (5 percent). The results of this study indicate that the ownership structure of public companies in the manufacturing sector has no effect on the timeliness of submitting the company's financial statements.

3) H3 : The reputation of the auditor / Public Accounting Firm that audits the financial statements of public companies in the manufacturing sector has an effect on the timeliness of submitting financial statements. The third hypothesis of this study suspects that the reputation variable of the auditor / Public Accounting Firm that audits the financial statements of public companies in the manufacturing sector has an effect on the timeliness of submitting financial statements. The KAP variable in table 4.5 of the regression model shows a negative coefficient value of -1.575 with a variable probability of 0.011 below the significance level 0.05 (5 percent). The results of this study indicate that the reputation of the auditor / Public Accounting Firm that audits the financial statements of public companies in the manufacturing sector has a negative effect on the timeliness of submitting the company's financial statements.

4) H4: The age of the company from a public company in the manufacturing sector has an effect on the timeliness of submitting financial reports. The fourth hypothesis of this study assumes that the variable age of the company from a public company in the manufacturing sector has an effect on the timeliness of submitting financial statements. The AGE variable in table 4.5 of the regression model shows a negative coefficient value of 0.152 with a variable probability of 0.077 above the significance level of 0.05 (5 percent). The results of this study indicate that the age of the company from a public company in the manufacturing sector has no effect on the timeliness of submitting financial statements.

5) H5: The size of the company affects the timeliness of the company's financial reporting. The fifth hypothesis of this study suspects that the firm size variable of a public company in the manufacturing sector affects the timeliness of submitting financial statements. The SIZE variable in table 4.5 of the regression model shows a positive coefficient value of 0.000 with a variable probability of 0.101 above the significance level of 0.05 (5 percent). The results of this study indicate that the company size of a public company in the manufacturing sector has no effect on the timeliness of submitting financial statements.

\section{CONCLUSION}

The results of the logistic regression test show that profitability has a positive effect on the timeliness of submitting the company's financial statements. The higher the profitability, the higher the timeliness of submitting financial statements, or vice versa if the lower profitability, the timeliness of submitting financial statements will also be lower.

The results of the logistic regression test show that the ownership structure measured by looking at the largest percentage of share ownership owned by outsiders in manufacturing companies has no effect on the timeliness of submitting the company's financial statements.

The results of the logistic regression test show that the auditor's reputation Public Accounting Firms have a negative effect on the timeliness of submitting financial reports. KAP affiliated with KAP The Big Four has a negative influence by slowing down the submission of the audited company's financial statements because it may be due to the busyness of the KAP affiliated with KAP The Big Four so that the completion of audit work is delayed.

The results of the logistic regression test show that the age of the company measured from the date of the company's listing in the capital market has no effect on the timeliness of submitting the company's financial statements.

The results of the logistic regression test show that the size of the company as measured by the total assets owned by the company has no effect on the timeliness of submitting the company's financial statements. 
Research findings indicate that public companies in the manufacturing sector tend to submit their company's financial statements on time during the period $2007-2010$. The number of companies that are on time in submitting their financial statements in 2007 reached $97.14 \%$, in 2008 reached $87.14 \%$, in 2009 reached $94.29 \%$ and in 2010 it reached $95.71 \%$. This shows that the company's level of attention to the timeliness of submitting its financial statements is getting better. Research findings indicate that during the period 2007 - 2010, Bapepam-LK has imposed an administrative fine of Rp. $155,000,000$ (one hundred and fifty five million rupiah) to 11 public companies in the manufacturing sector that were not timely in submitting their financial reports.

\section{REFERENCES}

Anissa, Nur, 2004. "Ketepatan Waktu Penyampaian Laporan Keuangan : Kajian Atas Kinerja Manajemen, Kualitas Auditor dan Opini Audit", Balance Nomor 2 (September), hal 42-53.

Aryati, Titik dan Maria Theresia, 2005. "Faktor-Faktor yang Mempengaruhi Audit Delay dan Timeliness", Media Riset Akuntansi, Auditing dan Informasi5(3): hal 271-287.

Astuti, Christina Dwi, 2007. "Faktor-faktor yang Berpengaruh Terhadap Ketepatan Waktu Pelaporan Laporan Keuangan", Skripsi,Universitas Trisakti, Jakarta.

Baron, Robert A dan Donn Bryne, 2000. Social Psychology:Understanding Human Interaction, $9^{\text {th }}$ Edition, Allyn and Bacon,Inc,Boston.

Brigham, Eugene F and Joel F.Houston, 2001.Fundamentals of Financial Management Alih Bahasa Dodo Suharto dan Herman Wibowo,Manajemen Keuangan, Edisi Kedelapan, Buku Satu, Erlangga, Jakarta.

Butler, Marty, Arthur Kraft and Ira S.Weiss, 2006. The Effect of Reporting Frequency on The Timeliness of Earnings: The Cases of Voluntary and Mandatory Interim Report. http://ssrn.com/abstract (15 Maret2012).

Catrinasari, Renni, 2006."Faktor - Faktor yang Mempengaruhi Ketepatan Waktu Pelaporan Keuangan Perusahaan Perbankan Go Publik di Bursa Efek Jakarta, Skripsi, Fakultas Ekonomi, Universitas Islam Indonesia, Yogyakarta.

Chariri, Anis dan Imam Ghozali, 2003. Teori Akuntansi, Badan Penerbit Universitas Diponegoro, Semarang.

Dwiyanti, Rini, 2010. "Analisis Faktor-Faktor yang Mempengaruhi Ketepatan Waktu Pelaporan Keuangan pada Perusahan Manufaktur yang Terdaftar di Bursa Efek Indonesia", Skripsi. Universitas Diponegoro, Semarang.

Erlina, 2008. Metodologi Penelitian Bisnis : Untuk Akuntansi dan Manajemen, Edisi Revisi, USU Press, Medan.

Ghozali, Imam, 2005. Aplikasi Analisis Multivariate dengan Program SPSS, Edisi 3, Badan Penerbit Universitas Diponegoro, Semarang.

Harahap, Sofyan, 2004. Analisa Kritis Atas Laporan Keuangan, PT Raja Grafindo Persada, Jakarta.Ikatan Akuntan Indonesia, 2007. Standar Akuntansi Keuangan, Salemba Empat, Jakarta.

Ikatan Akuntan Indonesia, 2008. Standar Akuntansi Keuangan, Salemba Empat, Jakarta.

Ikatan Akuntan Indonesia, 2009. Standar Akuntansi Keuangan, Salemba Empat, Jakarta.

Indonesian Capital Market Directory, 2008. Indonesian Capital Market Directory, 2009. Indonesian Capital Market Directory, 2010.

Leventis, S dan Weetman, 2004. "Timeliness of Financial Reporting:Applicability of Disclosure Theories in an Emerging Capital Market”, Accounting and Business Research, Vol. 34 Nomor 1, pp. 43-56.

Mcgee, R.W, 2006. Timeliness of Financial Reporting in The Russian Energy Sectors, http://ssrn.com/abstract (15 Maret 2012).

McGee, R.W. dan Yuan, X, 2008. Corporate governance and the timeliness of financial reporting: an empirical study of the people's republic of China, http://ssrn.com/abstract (15 Maret 2012).

Mentari, Pamor, 2007."Analisis Faktor-Faktor yang Mempengaruhi Ketepatan Waktu Publikasi Laporan Keuangan ke Publik Studi Kasus pada Perusahaan Manufaktur di Bursa Efek Indonesia”, Skripsi, Fakultas Ekonomi, Universitas Sumatera Utara, Medan.

Muchamad, Syafruddin, 2001. "The Effect of Timeliness of Financial Reporting on Earnings Response Coeficients: A Prelimanary Empirical Study in Jakarta Stock Exchange",Paper forThe Fourth Asian Academy of Management (AAM) Conference 2001: Proceedings, Johor Bahru, Malaysia, hal 24-33.

Munawir, 2004. Analisa Laporan Keuangan, Liberty, Yogyakarta.

Na'im,Ainun, 1999. "Nilai Informasi Ketepatan Waktu Penyampaian Laporan Keuangan: Analisis Empirik Regulasi Informasi di Indonesia", Jurnal Ekonomi dan Bisnis Indonesia (14:2), April, p.85-99.

Oktorina, Mega dan Suharli, Michell, 2005. "Studi Empiris terhadap Ketepatan Waktu Pelaporan Keuangan", Jurnal Ekonomi dan Bisnis, Universitas Katolik Indonesia Atma Jaya, Jakarta.

Owusu, Stephen \& Ansah, 2000. "Timeliness of Corporate Financial Reporting in Emerging Capital Market: Empirical Evidence From The Zimbabwe Stock Exhange", Accounting and Business Research, Volume 30 Nomor 3 Summer 2000, http://ssrn.com/abstract (15 Maret2012). 
Rachmawati, Sistya, 2005. "Pengaruh Faktor Internal dan Eksternal Perusahaan Terhadap Audit Delay dan Timeliness “, Jurnal Akuntansi dan Keuangan, Volume 10 Nomor 1, Universitas Indonesia, Jakarta.

Respati, Novita WeningTyas, 2001. "Faktor-Faktor Yang Mempengaruhi Terhadap Ketepatan Waktu Pelaporan Keuangan : Studi Empiris di Bursa Efek Jakarta", Tesis, Program Pasca Sarjana Magister Sains Akuntansi Universitas Diponegoro, Semarang.

Rochaety, Ety, Ratih Tresnati dan H.A Madjid Latief, 2007. Metodologi Penelitian Bisnis:Dengan aplikasi SPSS, Edisi Pertama, Mitra Wacana Media, Jakarta.

Saleh, Rachmat, 2004. "Studi Empiris Ketepatan Waktu Pelaporan Keuangan Perusahaan Manufaktur di Bursa Efek Jakarta". Simposium Nasional Akuntansi VII, Denpasar.

Sulistyo, Wahyu Adhi Noor, 2010. "Analisis Faktor-faktor yang Berpengaruh terhadap Penyampaian Laporan Keuangan pada Perusahaan yang Listing di Bursa Efek Indonesia pada Periode 2006-2008", Skripsi, Fakultas Ekonomi Universitas Diponegoro, Semarang.

Wijayanti, Ambar, 2008. "Faktor-faktor yang Mempengaruhi Ketepatan Waktu Pelaporan Keuangan pada Perusahaan Go Publik di Bursa Efek Jakarta tahun 2004-2005”. Skripsi,Fakultas Ekonomi Universitas Gajah Mada, Yogyakarta.

Wild, Jhon. J, K.R Subramanyam dan Robert F. Halsey, 2005. Analisis Laporan Keuangan, Alih Bahasa Yanivi S.Bachtiar dan S.Nurwahyu Harahap, Edisi 8, Buku 1, Salemba Empat, Jakarta. 